\title{
Expression of P63, P16 and CK17 in Atypical Squamous Metaplasia and Cervical Intraepithelial Neoplasia
}

\author{
Maryam Iranpour $^{1}$ (D), Shahriar Dabiri ${ }^{1 *}$ (D), Mitra Rezazade-Jabalbarezi ${ }^{1}$, Fatemeh Bagheri $^{1}$ \\ 1. Department of Pathology, Pathology and Stem Cell Research Center, Faculty of Medicine, Kerman University of Medical Sciences, Kerman, \\ Iran
}

\begin{tabular}{c}
\hline KEYWORDS \\
\hline Cervical intraepithelial neoplasia, \\
P63, P16, CK17 \\
Scan to discover online \\
口 \\
Dain Subjects: \\
Gynecologic Pathology \\
Received 07 Apr 2020; \\
Accepted 08 Oct 2020; \\
Published Online 26 Dec 2020; \\
\hline
\end{tabular}

ABSTRACT

10.30699/IJP.2021.104280.2095

\begin{tabular}{ll}
\hline Corresponding Information: & $\begin{array}{l}\text { Shahriar Dabiri, Department of Pathology, Pathology and Stem Cell Research Center, Faculty of Medicine, Kerman } \\
\text { University of Medical Sciences, Kerman, Iran Email: dabiri12@yahoo.com }\end{array}$
\end{tabular}

Copyright $(C 2021$. This is an open-access article distributed under the terms of the Creative Commons Attribution- 4.0 International License which permits Share, copy and redistribution of the material in any medium or format or adapt, remix, transform, and build upon the material for any purpose, even commercially.

\section{Introduction}

Annually, a total of 330,000 new cervical intraepithelial neoplasia (CIN) cases is reported in the European Union, with relatively half of them diagnosed as CIN I (1). A usually long pre-invasive process capable of developing into invasive cervical carcinoma over time; $\mathrm{CIN}$ is microscopically considered as a series of events which progress from cellular atypia to various grades of dysplasia (2).

In accordance with new WHO classification, $\mathrm{CIN}$ is categorized into Low-Grade Squamous Intraepithelial Lesion (LSIL) and High-Grade Squamous Intraepithelial Lesion (HSIL) terminology (2). However, based on the degree of dysplasia, previous classifications grouped it into CIN I, CIN II, and CIN III (3). As CIN lesions were monitored and treated in different ways, precise histological grading of CIN lesions assumed of great significance with regard to clinical management of patients. For example, due to its regression in about $80 \%$ of cases, CIN I was usually regarded as benign and no therapy was indicated (4). Nevertheless, CIN II and CIN III were considered as precursors to invasive carcinomas and therapy (conization or other less invasive procedures) was indicated since $0.2 \%$ to $4.0 \%$ of cases with CIN II and CIN III can progress to cervical carcinoma within 12 months (4). It is worth noting that there were no specific clinical symptoms to demonstrate the presence of CIN (5).

In fact, diagnosis of these precursor forms can result in inter-observer variability in comparison with its reactive mimics, such as atypical squamous metaplasia (ASM), immature squamous metaplasia (ISM), reactive/reparative atypia (RA), atrophy, reserve cell/basal cell hyperplasia, etc. Overall, this highlights the need for specific biomarkers to contribute to objective CIN grading and differentiation of true high-grade cervix dysplasia from its mimics (6).

Human papillomavirus (HPV) infection of any type was shown to be related to a 498-fold increase in the risk of cervical cancer development. In comparison to females infected with HPV-16, patients infected with HPV-18 had a higher risk of cervical cancer. The high-risk viruses have a crucial role in the carcinogenic process through production of two oncoproteins encoded by the viral E6 and E7 genes. Directly involved in inactivation of p53 and 
$\mathrm{pRb}$, respectively, these oncoproteins promote progressive cell cycle and DNA synthesis by blocking apoptosis, thus contributing to viral replication (7).

A tumor suppressor protein, P16 is biologically tasked with regulating cell cycle progression at the $\mathrm{G} 1 / \mathrm{S}$ boundary (8), thus demonstration the value of P16 would be as a diagnostic marker for cervical dysplasia and cervical carcinoma (9).

Cytokeratin-17 (CK17), which is an efficient marker for detection of cervical stem cells, is expressed in reserve cells and immature metaplastic cells. However, its expression is not reported in cervical glandular epithelial cells, squamous cells in the portio, or mature squamous metaplastic cells (10).

The areas where P63, a member of the P53 gene family, is expressed include the basal and parabasal cells of mature cervical, vaginal and vulvar squamous epithelium, as well as cervical reserve cells at the transformation zone, immature metaplastic cells, and atrophic cervical squamous epithelium. Instead of Ki67, the present study considers P63 as CIN and squamous metaplasia, e.g., basal cell hyperplasia are mostly the result of basal cell, reserve cell, and stem cell hyperplasia (6).

In order to evaluate the status of HPV infection in cervix, the present study analyzed the most common histological alterations occurring in the cervix, such as squamous metaplasia, CIN 1, CIN 2, CIN 3, as well as expression of the biomarkers of P16, CK17, and P63.

\section{Materials and Methods}

\section{Patients}

Based on the pathological reports available in the laboratory of Afzalipour Hospital and Besat Clinic, 50 patients with ASM and 50 patients with CIN were enrolled in the study. The study protocol was approved by the Ethics Committee of Kerman University of Medical Sciences, Iran.

\section{Immunohistochemical (IHC) Staining}

The tissue samples were histopathologically examined by two experts. Formalin-fixed paraffinembedded tissue was cut in sections with $4 \mu \mathrm{m}$ thickness, which were then placed on slides, dehydrated by alcohol washes, and cleared using a detergent like xylene before being imaged under a microscope. Sections were incubated in $5.0 \% \quad \mathrm{H}_{2} \mathrm{O}_{2}$ to quench endogenous peroxidase activity. Furthermore, antigens were also retrieved by digesting the tissue sections with a proteolytic enzyme like trypsin. To decrease the degree of background staining in IHC, the samples were incubated with a buffer, blocking the non-specific sites to which the primary or secondary antibodies may otherwise bind such as normal serum. The slides were then incubated 30 minutes at room temperature with primary antibodies against the antigens including, P16 (rabbit monoclonal), P63, and CK17. In order to detect a biotinylated secondary antibody, the study adopted streptavidin for biotin. To visualize bonding of antibodies, $3,3 \mu$ - diaminobenzidine tetrahydrochloride (DAB) was applied as chromogen for 5 minutes, and the sections were counterstained in hematoxylin for 2 minutes.

\section{Evaluation of P16, CK17 and P63 Expression}

The immunoreactivity of P16 and P63 was shown to be positive since more than $50 \%$ and $10 \%$ of the tumor cell nuclei indicated a strong intensity, respectively. The P16 was considered as positive when it showed nuclear and continuous cells diffuse cytoplasmic staining in the basal and para-basal squamous epithelium cell layers, which variably reached intermediate and superficial cell layer characteristic of a diffuse staining pattern. Additionally, P16 was shown to be negative when it was completely unstained or demonstrated a focal or sporadic epithelial staining, not characterized by basal and parabasal cells (focal staining pattern). CK17 staining indicated to be positive when cytoplasmic staining involved all squamous cell layers. Furthermore, focal staining or completely unstained cell layers were considered as negative.

\section{Statistical Analysis}

The data were analyzed by IBM SPSS Statistics for Windows, version 20 (IBM Corp., Armonk, N.Y., USA) using the statistical methods such as Chi square test and screening test. The statistical significance was considered to be 0.05 .

\section{Results}

Out of 100 patients included in the study, 59 and 41 subjects were diagnosed with CIN and ASM, respectively. Considering an appropriate staining, the samples were enrolled for interpretation based on the distribution, localization, and pattern of involvement. Figures 1-A and 1-B show exocervical tissue with nuclear elongation and dysmaturation of squamous epithelial cells in the lower two thirds of exocervical tissue and Figure 1C shows squamous metaplasia. 

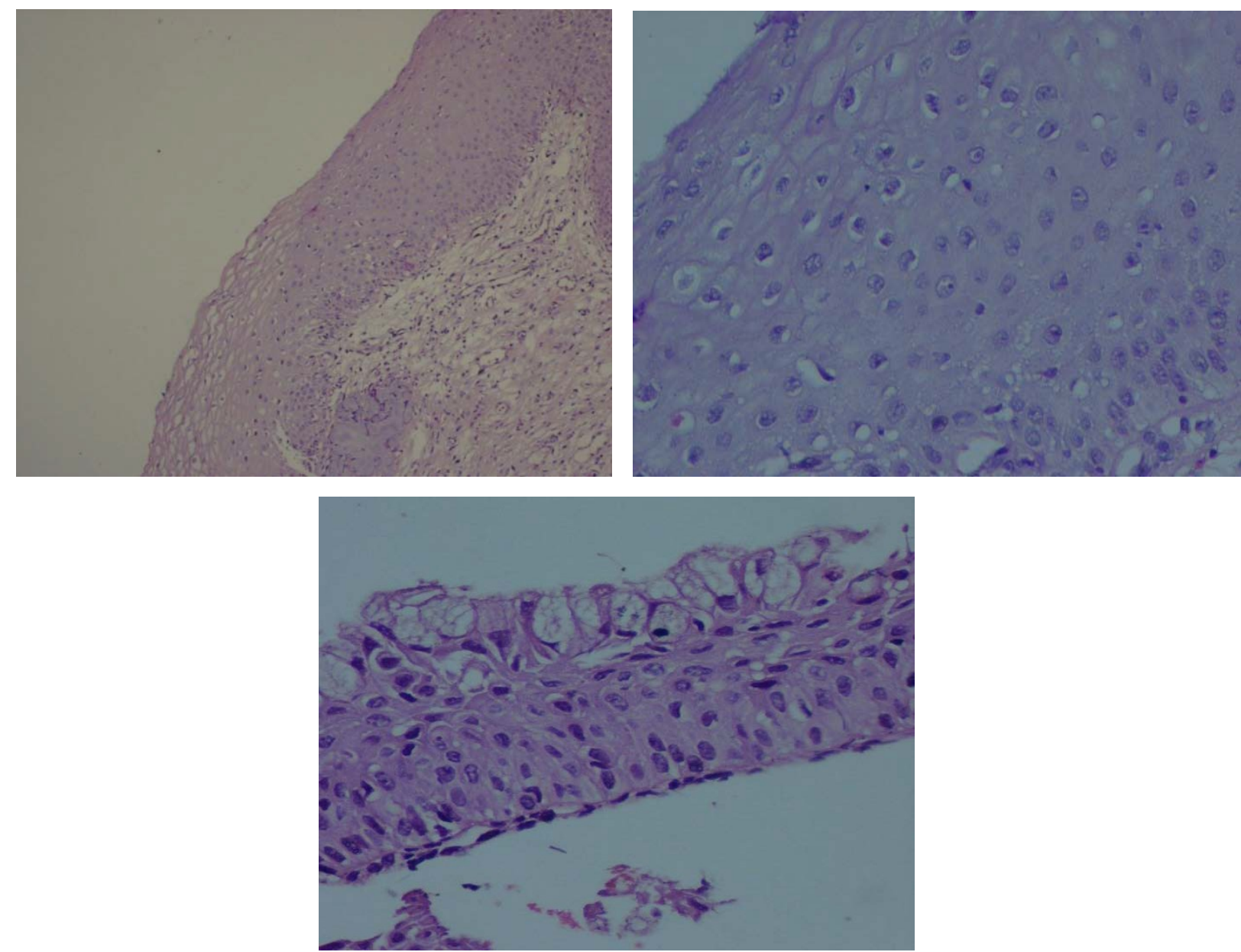

Fig. 1. H\&E Staining, Moderate Dysplasia. A) $\times 100$; B) $\times 400$; C) Squamous metaplasia.

\section{P63 Expression}

In ASM, $8(19.5 \%)$ cases were positive for $\mathrm{P} 63$ (Table 1). In the group with ASM and high grade CIN, $61 / 100$ patients were positive for P63. In the high grade CIN group, $53(89.8 \%)$ subjects showed positive P63 (Table 2). Moreover, P63 was found to be a statistically significant marker $(P<000)$ with regard to differentiating CIN from ASM. Figures 2-A and 2-B show nuclear staining of P63, indicating a positive reaction in atypical squamous epithelial cells in the lower two thirds of exocervical tissue, and Figure 2-C shows nuclear staining of P63 indicating a negative reaction in squamous metaplastic cells.

Table 1. P63 Staining in Atypical Squamous Metaplasia

\begin{tabular}{|c|c|c|c|}
\hline Tissue & P63 & Frequency & Percent \\
\hline \multirow{3}{*}{ Metaplasia } & Positive & 8 & $\mathbf{1 9 . 5} \%$ \\
& Negative & 33 & $\mathbf{8 0 . 5} \%$ \\
\cline { 2 - 4 } & Total & $\mathbf{4 1}$ & $\mathbf{1 0 0} \%$ \\
\hline
\end{tabular}

Table 2. P63 Staining in High Grade CIN

\begin{tabular}{|c|c|c|c|}
\hline Tissue & P63 & Frequency & Percent \\
\hline \multirow{2}{*}{ Dysplasia } & Positive & 53 & $\mathbf{8 9 . 8} \%$ \\
\cline { 2 - 4 } & Negative & 6 & $\mathbf{1 0 . 2} \%$ \\
\hline
\end{tabular}




\begin{tabular}{|c|c|c|}
\hline \hline Total & 59 & $100 \%$ \\
\hline
\end{tabular}

Abbreviations: CIN, Cervical Intraepithelial Neoplasia.
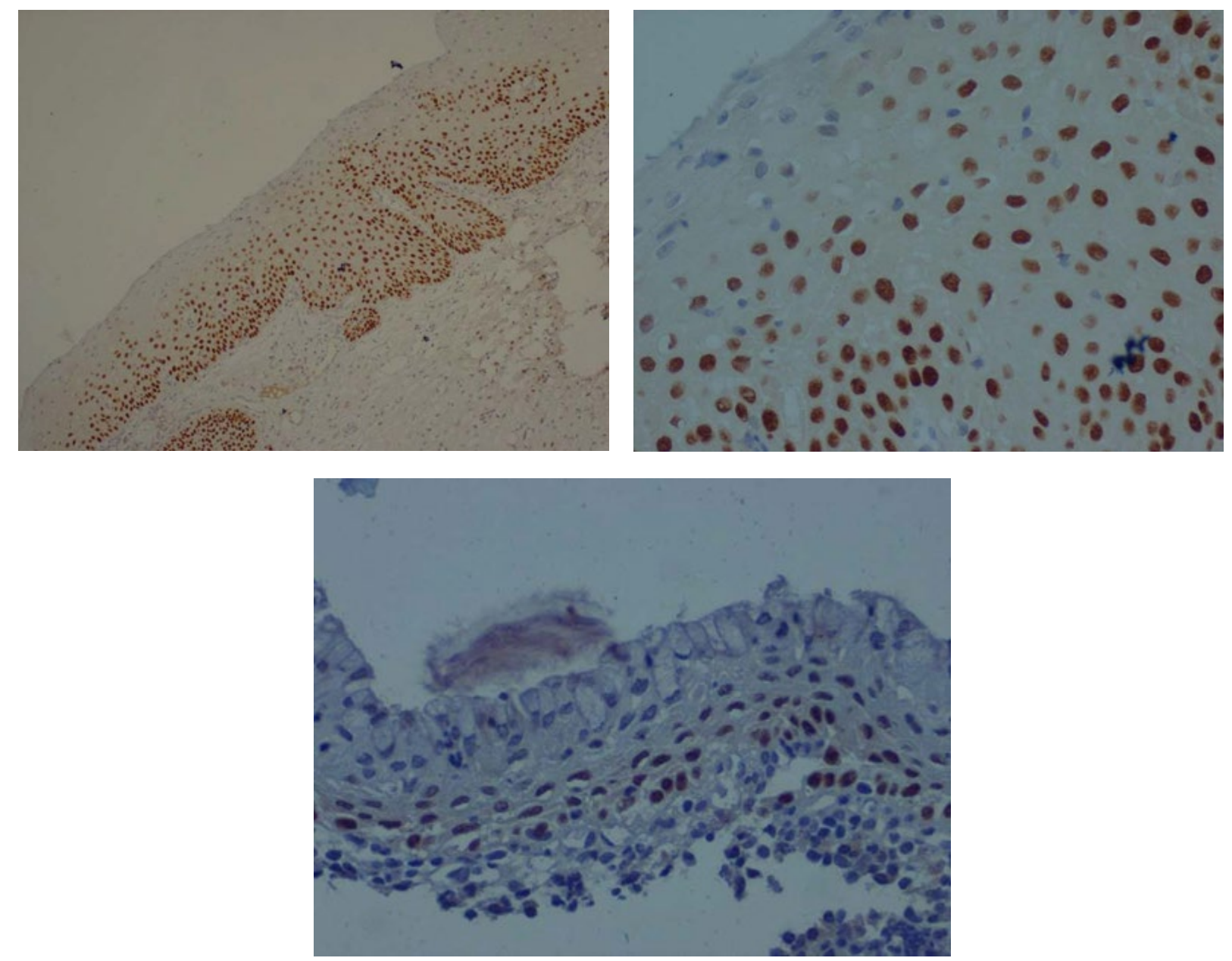

Fig. 2. Positive nuclear staining of $\mathrm{P} 63$ in dysplastic cells. A) $\times 100$; B) $\times 400$; C) Negative staining of nuclear P63 in squamous metaplastic cells.

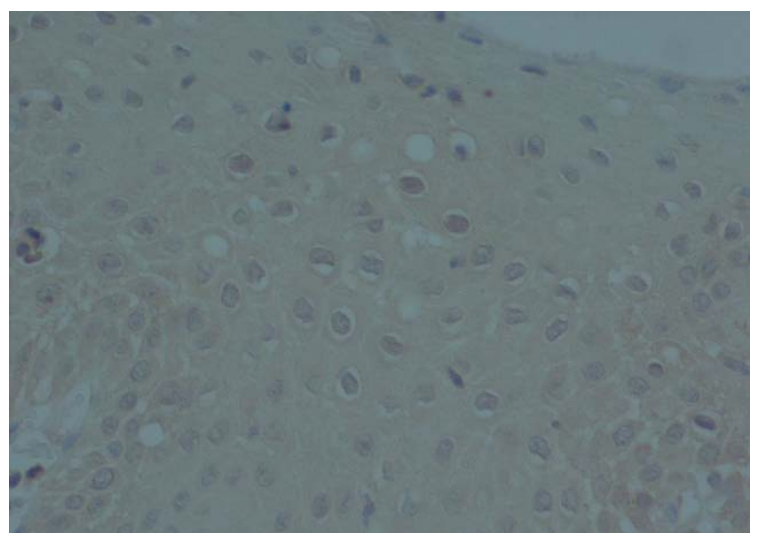

\section{P16 Expression}

P16 was shown to be positive in $30 \%$ of all cases. Moreover, $30(50.8 \%)$ CIN cases showed positivity whereas No positivity for P16 was found in ASM and squamous metaplasia (100\%), while $50.8 \%$ of the cases of dysplasia showed positive reactivity for that marker
Fig. 3. Immunohistochemical Staining of P16.

(Tables 3 and 4). According to the findings, there was a strong relationship between $\mathrm{P} 16$ expression and progression of the lesion with a $\mathrm{P}$-value $<0.00$. Figure 3 demonstrates immunoreactivity of P16 that was negative in basal and atypical squamous epithelial cells. 
Table 3. P16 Staining in Atypical Squamous Metaplasia

\begin{tabular}{|c|c|c|c|}
\hline Tissue & P16 & Frequency & Percent \\
\hline \multirow{3}{*}{ Metaplasia } & Positive & 0 & $\mathbf{0}$ \\
\cline { 2 - 4 } & Negative & 41 & $\mathbf{1 0 0} \%$ \\
\cline { 2 - 4 } & Total & $\mathbf{4 1}$ & $\mathbf{1 0 0} \%$ \\
\hline
\end{tabular}

Table 4. P16 Staining In High Grade CIN

\begin{tabular}{|c|c|c|c|}
\hline \multirow{2}{*}{ Tissue } & P16 & Frequency & Percent \\
\hline \multirow{3}{*}{ Dysplasia } & Positive & 30 & $\mathbf{5 0 . 8} \%$ \\
\cline { 2 - 4 } & Negative & 29 & $\mathbf{4 9 . 2} \%$ \\
\cline { 2 - 4 } & Total & $\mathbf{5 9}$ & $\mathbf{1 0 0} \%$ \\
\hline
\end{tabular}

Abbreviations: CIN, Cervical Intraepithelial Neoplasia.

\section{CK17 Expression}

CK17 was found to be positive in $43 \%$ of all cases. CIN showed $8.5 \%$ positivity whereas ASM showed $92.7 \%$ positivity (Tables 5 and 6 ). CK17 was statistically insignificant $(P=0.0)$ in terms of distinguishing CIN from ASM. Figures 4-A and 4-B show positive immunoreactivity of CK 17 only in basal layer, which was negative in atypical squamous, and
Figure 4-C shows positive cytoplasmic of CK17 in squamous metaplastic cells. P63 was found to be positive in $50.28 \%$ of all the case that $89.8 \%$ were diagnosed as dysplasia and $19.5 \%$ showed metaplasia. P16 was found to be positive in $29.78 \%$ of all the cases, of which $50.8 \%$ diagnosed as dysplasia. CK17 was found to be positive in $69.8 \%$ of all the case of which $8.5 \%$ showed dysplasia and $92.7 \%$ demonstrated metaplasia (Table 7)

Table 5. CK17 Staining In Atypical Squamous Metaplasia

\begin{tabular}{|c|c|c|c|}
\hline \multirow{2}{*}{ Tissue } & CK17 & Frequency & Percent \\
\hline \multirow{3}{*}{ Metaplasia } & Positive & 38 & $\mathbf{9 2 . 7} \%$ \\
\cline { 2 - 4 } & Negative & 3 & $\mathbf{7 . 3} \%$ \\
\hline & Total & $\mathbf{4 1}$ & $\mathbf{1 0 0} \%$ \\
\hline
\end{tabular}

Abbreviations: CK17, cytokeratin17.

Table 6. CK17 Staining In High Grade CIN

\begin{tabular}{|c|c|c|c|}
\hline \multirow{2}{*}{ Tissue } & CK17 & Frequency & Percent \\
\hline \multirow{3}{*}{ Dysplasia } & Positive & 5 & $\mathbf{8 . 5} \%$ \\
\cline { 2 - 4 } & Negative & 54 & $\mathbf{9 1 . 5} \%$ \\
\cline { 2 - 4 } & Total & $\mathbf{5 9}$ & $\mathbf{1 0 0} \%$ \\
\hline
\end{tabular}

Abbreviations: CIN, Cervical Intraepithelial Neoplasia; CK17, Cytokeratin17.

Table 7. Summary of Immunohistochemical Staining Profile, Atypical Squamous Metaplasia and Cervical Intraepithelial Neoplasia (CIN).

\begin{tabular}{|c|c|c|c|c|c|c|}
\hline $\begin{array}{c}\text { IHC } \\
\text { Markers }\end{array}$ & Diagnosis & Positive & Negative & $\begin{array}{c}\text { Pearson Chi- } \\
\text { Square }\end{array}$ & DF & $\begin{array}{c}\text { Asymp. Sig. } \\
\text { (2-sided) }\end{array}$ \\
\hline $\mathbf{P 6 3}$ & Dysplasia & $89.8 \%$ & $10.2 \%$ & 50.28 & 1 & $\mathbf{. 0 0 0}$ \\
\hline & Metaplasia & $19.5 \%$ & $80.5 \%$ & & & \\
\hline
\end{tabular}




\begin{tabular}{|c|c|c|c|c|c|c|}
\hline \multirow{2}{*}{ P16 } & Dysplasia & $50.8 \%$ & $49.2 \%$ & \multirow{2}{*}{29.78} & \multirow{2}{*}{1} & \multirow{2}{*}{.000} \\
\hline & Metaplasia & $0 \%$ & $100 \%$ & & & \\
\hline \multirow{2}{*}{ CK17 } & Dysplasia & $8.5 \%$ & $91.5 \%$ & \multirow{2}{*}{69.98} & \multirow{2}{*}{1} & \multirow{2}{*}{.000} \\
\hline & Metaplasia & $92.7 \%$ & $7.3 \%$ & & & \\
\hline
\end{tabular}

Abbreviations: CIN, Cervical Intraepithelial Neoplasia; CK17, Cytokeratin 17; IHC, Immunohistochemistry.
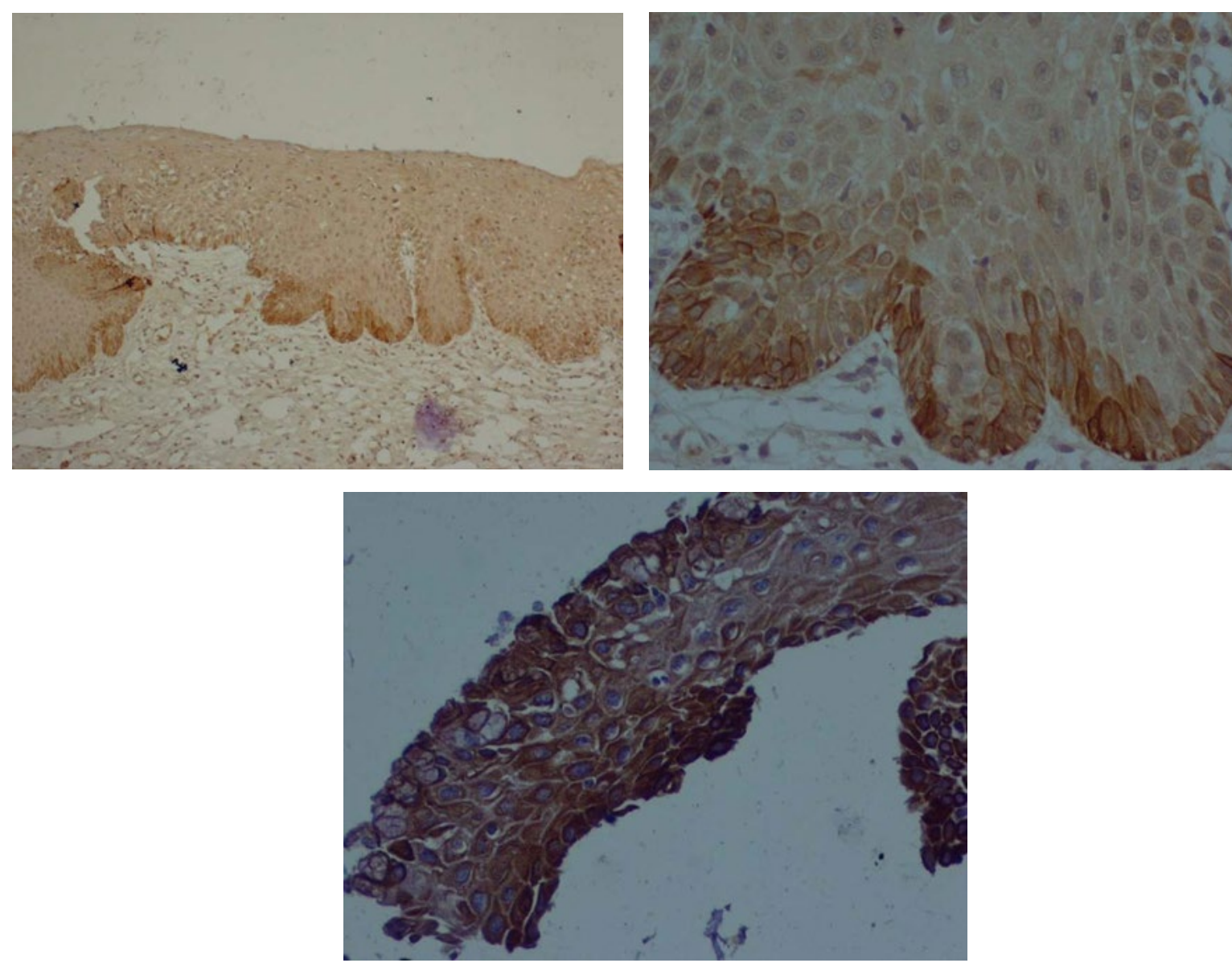

Fig. 4. Cytoplasmic Staining of CK17 in basal layer. A) $\times 100$; B) $\times 400$; C) Positive cytoplasmic staining of CK17 in squamous metaplastic cells

\section{Discussion}

Cervical cancer is the first cause of cancer in females aged 15-45 years old, suggesting that the main etiology is the young age for the onset of sexual intercourse. In this study, IHC staining was used to examine the expression of P16, P63, and CK17 to distinguish high grade CIN lesions from ASM. According to the research results, P63 expression was found to be $89.8 \%$ and $19.5 \%$ in dysplasia and metaplasia, respectively. Furthermore, the expression of P63 in CIN was increased significantly compared to metaplasia. However, it is still unknown whether P63 is a tumor suppressor gene or an oncogene (11). On the other hand, applying P63 in metastatic and primary tumors is controversial $(9,12$, and 13). Findings of the present study revealed that P63 significantly increased in dysplasia lesions. The expression of P63 gene in tumor lesions has also been reported in a number of other studies whose results were similar to those of ours. However, the results of few studies were inconsistent with our findings $(5,13$, and 14). The present study supports the findings of Regauer S \& Reich O (2007), which suggested the increase in marker P63 was directly correlated with the degree of labelling and the degree of dysplasia (15). In the study by Selvi et al. (2014), P63 expression reported in $343 / 350$ cases $(98 \%)$ showed positivity, while it was negative in $7 / 350$ cases $(2 \%)$ (6). This pattern of positivity is comparable with a few previous studies, including Jolise (2004) and Quade (2001) that analyzed P63 expression in CIN; they concluded that P63 expression has an increasing trend in high-grade CIN $(14,16)$. In addition, it has been shown that $\mathrm{P} 63$ can be 
utilized to make a distinction between a proliferating epithelium (CIN, ISM, and basal cell hyperplasia) and normal/non-proliferating epithelium (RA) (6).

With regard to findings of the present study, P16 staining of metaplasia samples is $100 \%$ negative. Meanwhile, it was also shown that the presence of P16 was positive in $50.8 \%$ of the dysplasia samples. As a cyclin-dependent kinase inhibitor, P16 acts as a tumor suppressor (17). Recent studies have shown some neoplasia, including cervical cancer where P16 is overexpressed (18-20). The effect of feedbacks capable of suppressing the tumor accounts for the increase in this marker during epithelial damage (15).

The research carried out by Regauer S \& Reich O (2007) concluded that immature metaplasia had consistent characteristics like strong, uniform CK17 staining of the proliferating cells alongside P16 negativity, whereas high-grade dysplasias/CIN III revealed a mirror image IHC profile characterized by strong diffuse staining of all dysplastic proliferating cells with P16 (15). Furthermore, the study by Xing et al. (2017) stated that P16 marker might be a biomarker contributing to making a distinction between CIN1 and CIN2/3 (21). Cervical lesions are shown to be generally associated with positive P16, though the results vary from one study to another, depending on the degree of lesions and immunity. The highest level of heterogeneity is seen in CIN I category, while P16 expression ranges from $35 \%$ (22) to $100 \%$ (23). Although P16 was reportedly positive in more than $90 \%$ and up to $100 \%$ in CIN II and CIN III grades (23, 24 ), a high negative ratio (up to $33 \%$ ) has been also reported (22). In many cases, P16 can help distinguish CIN from similar cases, hence being an efficient factor in accurate diagnosis and proper management of patients in addition to histomorphology, as recommended by many studies $(25,26)$.

With regard to $\mathrm{CK} 17$, this marker showed an overall positivity of $97 \%$ in squamous metaplasia, even though its expression in dysplasia tissue declined by $8.5 \%$, which was statistically significant.

Regauer S \& Reich O (2007) maintained that metaplasia showed a strong expression for CK17 marker while dysplasia was negative for CK17; they suggested that CK17 marker can be employed in IHC method to differentiate metaplasia from dysplasia, which is a finding in line with that of the present study (15). Coinciding with results of this study, the findings obtained by Sari Aslani et al. (2013) showed that IHC staining for CK17 can be positive in metaplasia, and in some CIN lesions (27). Also, Selvi et al. (2014) concluded that CK17 has varied positivity in both CIN and the benign mimics, and that positivity is the result of more staining. They stated that, contrary to this study, HIC is useful for distinguishing different degrees of CIN from each other and from its benign mimics (6). In another study, Escobar-Hoyos et al. (2013) reported that CK17 can have a diagnostic utility for cervical squamous metaplasia (28), a finding supporting our evidence. Nonetheless, both studies by
Smedts et al. do not agree with viewing CK17 marker as a diagnostic utility for squamous metaplasia, claiming that CIN is positive only in reserve cells and in varying degrees $(29,30)$. This result is contrary to that of the present study. Differences experienced in various studies may be due to the fact that CIN cases in Iran are not common compared to other countries.

\section{Conclusion}

When difficulties are encountered with histomorphology to make a definite and accurate diagnosis of CIN, a combination of P16, P63, and CK17 markers would be useful for distinguishing CIN from its mimics. Further studies are needed, especially on other markers.

\section{Acknowledgements}

The authors thank Mrs. Sheikhshoai for her sincere technical support.

\section{Conflict of interest}

The authors had no conflict of interest to report.

\section{References}

1. Baak J, Kruse AJ, Janssen E, van Diermen B. Predictive testing of early CIN behaviour by molecular biomarkers. Cell Oncol.2005;27:277-80.

2. Kurman RJ, Carcangiu ML, Herrington CS, Young RH. WHO Classification of Tumours. 4th ed. Lyon: WHO; 2014.

3. Martin CM, O'Leary JJ. Histology of cervical intraepithelial neoplasia and the role of biomarkers. Best Pract Res Clin Obstet Gynaecol. 2011 Oct 1;25(5):605-15. [DOI:10.1016/j.bpobgyn.2011.04.005] [PMID]

4. Gurrola-Díaz CM, Suárez-Rincón ÁE, VázquezCamacho G, Buonocunto-Vázquez G, RosalesQuintana S, Wentzensen N, von Knebel Doeberitz M. P16INK4a immunohistochemistry improves the reproducibility of the histological diagnosis of cervical intraepithelial neoplasia in cone biopsies. Gynecol Oncol. 2008 Oct 1;111(1):120-4. [DOI:10.1016/i.ygyno.2008.06.032] [PMID]

5. Mitildzans A, Arechvo A, Rezeberga D, Isajevs S. Expression of p63, p53 and Ki-67 in patients with cervical intraepithelial neoplasia. Turk Patoloji Derg. 2017 Jan 1;33:9-16. [DOI:10.5146/tjpath.2016.01373] [PMID]

6. Selvi K, Badhe BA, Papa D, Nachiappa Ganesh R. Role of p16, CK17, p63, and human papillomavirus in diagnosis of cervical intraepithelial neoplasia and distinction from its mimics. Int J Surg Pathol. 2014 May;22(3):221-30. [DOI:10.1177/1066896913496147] [PMID]

7. Jacob AA, Sundaram A. P16, Ki67 and P63 staining pattern in squamous metaplasia, $\mathrm{CIN}$ and cervical cancer. Int J Res Med Sci. 2018 Mar;6(3):882. [DOI:10.18203/2320-6012.ijrms20180608] 
8. Ruas M. The $\mathrm{p} 16 / \mathrm{CDKN} 2 \mathrm{~A}$ tumor suppressor and its relatives. Biochim Boophys Acta. 1998;1378:11577. [DOI:10.1016/S0304-419X(98)00017-1]

9. Kim SM, Lee JU, Lee DW, Kim MJ, Lee HN. The prognostic significance of p16, Ki-67, p63, and CK17 expression determined by immunohistochemical staining in cervical intraepithelial neoplasia 1. Korea J Obstet Gynecol. 2011 Apr 1;54(4):184-91. [DOI:10.5468/KJOG.2011.54.4.184]

10. Martens J, Baars J, Smedts F, Holterheus M, Kok MJ, Vooijs P, Ramaekers F. Can keratin 8 and 17 immunohistochemistry be of diagnostic value in cervical cytology? A feasibility study. Cancer Cytopathology: Interdisciplin Int J Am Cancer Soc. 1999 Apr 25;87(2):87-92. https://doi.org/10.1002/(SICI)10970142(19990425)87:2<87::AID-CNCR8>3.0.CO;2-L [DOI:10.1002/(SICI)10970142(19990425)87:23.0.CO;2-L]

11. Teissier S, Khalifa YB, Mori M, Pautier P, Desaintes C, Thierry F. A new E6/P63 pathway, together with a strong E7/E2F mitotic pathway, modulates the transcriptome in cervical cancer cells. J Virol. 2007 Sep 1;81(17):9368-76. [DOI:10.1128/JVI.00427-07] [PMID] [PMCID]

12. Singleterry WL, Henderson H, Cruse JM. Depletion of pro-inflammatory $\mathrm{CD} 161+$ double negative (CD3+ CD4- CD8-) T cells in AIDS patients is ameliorated by expansion of the $\gamma \delta \mathrm{T}$ cell population. Experiment Molecul Pathol. 2012 Feb 1;92(1):155-9. [DOI:10.1016/j.yexmp.2011.11.002] [PMID]

13. Saritha VN, Veena VS, Krishna KJ, Somanathan T, Sujathan K. Significance of DNA replication licensing proteins (MCM2, MCM5 and CDC6), p16 and p63 as markers of premalignant lesions of the uterine cervix: its usefulness to predict malignant potential. Asia Pacific J Cancer Prevent: APJCP. 2018;19(1):141.

14. Quade BJ, Yang A, Wang Y, Sun D, Park JJ, Sheets EE, Cviko A, Federschneider JM, Peters R, McKeon FD, Crum CP. Expression of the p53 homologue p63 in early cervical neoplasia. Gynecol Oncol. 2001 Jan 1;80(1):24-9. [DOI:10.1006/gyno.2000.5953] [PMID]

15. Garred P, Brygge K, Sorensen CH, Madsen HO, Thiel S, Svejgaard A. Mannan-binding protein-levels in plasma and upper-airways secretions and frequency of genotypes in children with recurrence of otitis media. Clin Experiment Immunol. 1993 Oct;94(1):99-104. 2249.1993.tb05984.x] [PMID] [PMCID]

16. Martens JE, Arends J, Van Der Linden PJ, De Boer BA, HELMERHORST TJ. Cytokeratin 17 and p63 are markers of the HPV target cell, the cervical stem cell. Anticancer Res. 2004 Mar 1;24(2B):771-6.
17. Baker DJ, Childs BG, Durik M, Wijers ME, Sieben CJ, Zhong J, Saltness RA, Jeganathan KB, Verzosa GC, Pezeshki A, Khazaie K. Naturally occurring p16 Ink4a-positive cells shorten healthy lifespan. Nature. 2016 Feb;530(7589):184-9. [DOI:10.1038/nature16932] [PMID] [PMCID]

18. Sacks F. The Nutrition Source. Ask the Expert: Omega-3 Fatty Acids. 2008.

19. Sacks D. Clinical Diagnosis and Management by Laboratory Methods, John Bernard Henry, ed. Philadelphia: WB Saunders, 2001, 1512 pp., \$99.00. ISBN 0-7216-8864-0. Clin Chemist. 2001 Dec $1 ; 47(12): 2188-9$.

[DOI:10.1093/clinchem/47.12.2188]

20. Bibbo M, Klump WJ, DeCecco J, Kovatich AJ. Procedure for immunocytochemical detection of P16INK4A antigen in thin-layer, liquid-based specimens. Acta cytologica. 2002 Jan 1;46(1):25-9. [DOI:10.1159/000326711] [PMID]

21. Xing Y, Wang C, Wu J. Expression of geminin, p16, and Ki67 in cervical intraepithelial neoplasm and normal tissues. Medicine. 2017 Jun;96(26). [DOI:10.1097/MD.0000000000007302] [PMID] [PMCID]

22. Branca M, Ciotti M, Santini D, Di Bonito LU, Giorgi C, Benedetto A, Paba P, Favalli C, Costa S, Agarossi A, Alderisio M. p16INK4A expression is related to grade of CIN and high-risk human papillomavirus but does not predict virus clearance after conization or disease outcome. Int J Gynecol Pathol. 2004 Oct 1;23(4):354-65.

[DOI:10.1097/01.pgp.0000139639.79105.40] [PMID]

23. Keating JT, Cviko A, Riethdorf S, Riethdorf L, Quade BJ, Sun D, Duensing S, Sheets EE, Munger K, Crum CP. Ki-67, cyclin E, and p16 INK4 are complimentary surrogate biomarkers for human papilloma virus-related cervical neoplasia. Am J Surg Pathol. 2001 Jul 1;25(7):884-91. [DOI:10.1097/00000478-200107000-00006] [PMID]

24. Klaes R, Friedrich T, Spitkovsky D, Ridder R, Rudy W, Petry U, Dallenbach-Hellweg G, Schmidt D, von Knebel Doeberitz M. Overexpression of p16INK4A as a specific marker for dysplastic and neoplastic epithelial cells of the cervix uteri. Int J Cancer. 2001 Apr 15;92(2):276-84. [DOI:10.1002/ijc.1174] [PMID]

25. Redman R, Rufforny I, Liu C, Wilkinson EJ, Massoll NA. The utility of p16INK4a in discriminating between cervical intraepithelial neoplasia 1 and nonneoplastic equivocal lesions of the cervix. Archives Pathol Lab Med. 2008 May;132(5):795-9.

26. Ordi J, Garcia S, del Pino M, Landolfi S, Alonso I, Quintó L, Torné A. p16INK4a immunostaining identifies occult CIN lesions in HPV-positive women. International journal of gynecological pathology. 2009 Jan 1;28(1):90-7. [DOI:10.1097/PGP.0b013e31817e9ac5] [PMID] 
27. Aslani FS, Safaei A, Pourjabali M, Momtahan M. Evaluation of Ki67, p16 and CK17 markers in differentiating cervical intraepithelial neoplasia and benign lesions. Iran J Med Sci. 2013 Mar;38(1):15.

28. Escobar-Hoyos LF, Yang J, Zhu J, Cavallo JA, Zhai H, Burke S, Koller A, Chen EI, Shroyer KR. Keratin 17 in premalignant and malignant squamous lesions of the cervix: proteomic discovery and immunohistochemical validation as a diagnostic and prognostic biomarker. Modern Pathol. 2014 Apr;27(4):621-30.

[DOI:10.1038/modpathol.2013.166]

[PMID]
29. Smedts F, Ramaekers F, Troyanovsky S, Pruszczynski M, Robben H, Lane B, Leigh I, Plantema F, Vooijs P. Basal-cell keratins in cervical reserve cells and a comparison to their expression in cervical intraepithelial neoplasia. The American journal of pathology. 1992 Mar;140(3):601.

30. Smedts F, Ramaekers FC, Hopman AH. CK17 and p16 expression patterns distinguish (atypical) immature squamous metaplasia from high-grade cervical intraepithelial neoplasia. Histopathology. 2008 Mar;52(4):515-6. [DOI:10.1111/j.13652559.2008.02941.x] [PMID]

\section{How to Cite This Article}

dabiri, S., Iranpour, M., Rezazade, M., Bagheri, F. Expression of P63, P16 and CK17 in Atypical Squamous Metaplasia and Cervical Intraepithelial Neoplasia. Iranian Journal of Pathology, 2020; 16(02):182-189. doi: 10.30699/ijp.2021.104280.2095 